\title{
Integrating Operations Management Into Cost Systems: An Accounting Approach To Linear Programming
}

\author{
Dennis F. Togo, (E-mail: togo@unm.edu), University of New Mexico
}

\begin{abstract}
Managers rely on information from cost accounting systems in building operations management models to support their decision-making. Yet, the link between accounting and operations management techniques within a business information system can be improved. Cost accountants provide critical input for decision models, but, they often have difficulty using decision models and relating results back into the cost accounting information system. The Keano Macadamia Nut Company is a cross-functional exercise which illustrates a cost accounting system providing data for a linear programming problem; the use of linear programming to obtain a solution to a profit maximization problem, and a connection of the model's optimal solution back into the cost accounting system.
\end{abstract}

\section{INTRODUCTION}

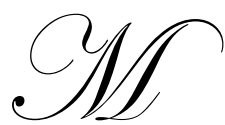

ost operations management textbooks (e.g., Albright \& Winston, 2005; ) are attempting to integrate the functional areas of business in their examples, which have tended to focus primarily on finance and marketing but less on accounting. While financial accounting problems may not be suited for operations management, cost accounting topics can be easily integrated with operations management through the modeling of managerial decisions. For example, models for capital budgeting, cash flows and income statements have utilized Monte Carlo simulation to perform risk analysis. Other cost accounting topics such as reciprocal service cost allocations, linear and curvilinear data analysis, and profit planning have benefited from the enhanced operations management capabilities of spreadsheets in solving simultaneous equations, linear regression, curvilinear modeling, and various statistical functions.

Cost accountants generate much of the quantitative information needed in support of managerial decisions. Their knowledge of relevant revenues and costs are critical for decisions such as capital budgeting, outsourcing, special orders, adding or dropping product lines, and the further processing of joint products (Garrison et al, 2006, Horngren et al, 2006). Furthermore, cost accountants prepare management reports using variable costing which is better suited for most managerial decisions than the traditional absorption costing. Yet, seldom do cost accounting systems fully integrate operations management techniques even when readily available. For example, learning curve historical data are seldom analyzed to determine their underlying curvilinear relationship and learning rate in preparing a cost estimate. Risk analysis is commonly taught with the use of scenarios; yet, the more complete stochastic approach utilizing probabilistic input data and output distributions are not commonly used in analyzing risk for management decisions.

The purpose of this paper is to integrate the operations management technique of linear programming (LP) into a cost accounting information system. Hence, data to an LP problem is generated from a cost accounting system, a solution is determined for a profit maximization LP problem, and the solution is linked back into the cost accounting system. This accounting approach to LP provides a cross-functional perspective to decision-making for both the accountant and manager. In contrast, most cost/managerial accounting textbooks and management science textbooks do not discuss where LP input data is obtained, and how the results can be linked back to the cost 
accounting system. In a following section, an integrative exercise illustrates cost accounting skills and LP skills to solve a realistic profit maximization problem, and to transfer its solution to an income statement.

\section{LINEAR PROGRAMMING AND COST ACCOUNTING}

Linear programming is an optimization technique used to maximize total contribution margin of a mix of products, given multiple constraints or requirements. Most cost/managerial accounting textbooks (e.g., Garrison et al, 2006; Horngren et al, 2006) present the graphical approach to linear programming in maximizing total contribution margin for two products given a few resource constraints. Even when the LP software SOLVER is available with EXCEL, only a few textbooks (e.g., Maher et al., 2003) illustrate linear programming as a tool to maximize profits or minimize costs. Furthermore, the direct link between the cost accounting system and the LP problem and its solution is not presented.

On the other hand, management science textbooks (e.g., Albright \& Winston, 2005) fully utilize LP software in their presentation for optimization techniques. Yet, seldom do they discuss how cost data was generated and how optimized results are brought back into the business information system. Although optimization techniques and cost accounting rely heavily on each other, they have not been presented in a cross-functional approach. A review of cost accounting assumptions used by linear programming is presented next. It is followed by an exercise emphasizing an accounting approach to linear programming.

\section{Relevant Accounting Information for $\mathrm{LP}$}

Only revenues and costs of products that vary proportionately with units sold and produced within the relevant range are used in linear programming. Therefore, the contribution margin per unit, which is defined as selling price less variable expenses, is critical in determining the mix of products that will maximize total contribution margin. Variable expenses consist of variable manufacturing expenses and variable selling and administrative (S\&A) expenses. Variable manufacturing expenses consist of direct materials, direct labor and variable manufacturing overhead. Variable selling and administrative (S\&A) expenses include sales commissions and delivery costs. Fixed costs for manufacturing and fixed costs for selling and administrative are not relevant in an LP problem because they do not change with units produced or sold within the relevant range of the decision.

\section{Contribution Income Statement}

In cost/managerial accounting, the contribution income statement (Exhibit 1) supports management decision-making by deducting expenses based on their behavior as either variable or fixed. From total contribution margin, fixed expenses are deducted to obtain operating income. The contribution income statement complements the objectives of LP when the contribution margin/variable expense for each available product is included in a maximizing/minimizing objective function. Another useful feature of the contribution income statement is its flexibility in accommodating different levels of sales and production within the relevant range. Exhibit 1 is a contribution income statement prepared for four products. For each product, the contribution income statement identifies total units sold, and total and per unit data for sales, variable expenses for direct materials, direct labor, manufacturing overhead, and S\&A, and contribution margin.

A common mistake by non-accountants in performing linear programming is the use of gross profit per unit instead of contribution margin per unit in a maximizing LP problem. This occurs because traditional income statements for a manufacturing firm computes gross profit as sales less all costs of manufacturing. Therefore, when gross profit/cost of goods sold is used in profit-maximizing/cost-minimizing LP problems, the mistake is that relevant variable S\&A expenses are not included and irrelevant fixed manufacturing costs are included in the analysis. Only the contribution margin/variable expenses of a product should be included in the maximizing/minimizing objective function for an LP problem.

The following LP exercise will maximize contribution margin for multiple products and multiple constraints/requirements. Given data for selling prices and costs of production, the contribution margin per unit will 
be determined and then used to find a mix of products that will maximize profits and still meet the various production constraints and sales requirements. The exercise will illustrate the LP add-in SOLVER available with EXCEL. This exercise can be adopted for use in cost/managerial accounting courses at the undergraduate and graduate levels.

\section{EXHIBIT 1: CONTRIBUTION INCOME STATEMENT}

\begin{tabular}{|c|c|c|c|c|c|c|c|c|c|}
\hline & & \multicolumn{2}{|c|}{ Whole } & \multicolumn{2}{c|}{ Cluster } & \multicolumn{2}{c|}{ Crunch } & \multicolumn{2}{c|}{ Roasted } \\
\hline & Total & Total & Unit & Total & Unit & Total & Unit & Total & Unit \\
\hline & & & & & & & & & \\
\hline Units sold & 2,182 & 1,209 & & 500 & & 373 & & 100 & \\
\hline Sales & 11,398 & 7,254 & 6.00 & 2,500 & 5.00 & 1,194 & 3.20 & 450 & 4.50 \\
\hline Variable expenses: & & & & & & & & & \\
\hline Direct materials & 2,626 & 1,548 & 1.28 & 560 & 1.12 & 358 & 0.96 & 160 & 1.60 \\
\hline Direct labor & 1,610 & 1,016 & 0.84 & 330 & 0.66 & 224 & 0.60 & 40 & 0.40 \\
\hline $\begin{array}{c}\text { Manuf. } \\
\text { overhead }\end{array}$ & 657 & 387 & 0.32 & 140 & 0.28 & 90 & 0.24 & 40 & 0.40 \\
\hline S\&A & 1,139 & 725 & 0.60 & 250 & 0.50 & 119 & 0.32 & 45 & 0.45 \\
\hline $\begin{array}{c}\text { Total } \\
\text { Contribution } \\
\text { margin }\end{array}$ & 6,032 & 3,676 & 3.04 & 1,280 & 2.56 & 791 & 2.12 & 285 & 2.85 \\
\hline Fixed expenses: & 5,366 & 3,578 & 2.96 & 1,220 & 2.44 & 403 & 1.08 & 165 & 1.65 \\
\hline $\begin{array}{c}\text { Manuf overhead } \\
\text { S\&A }\end{array}$ & 750 & & & & & & & & \\
\hline Operating income & $\mathbf{1 , 0 0 0}$ & & & & & & & & \\
\hline
\end{tabular}

\section{LP EXERCISE: KEANO MACADAMIA NUT COMPANY}

Keano Macadamia Nut Company located on the Big Island of Hawaii makes four different products chocolate covered whole nuts, chocolate nut clusters, chocolate nut crunch bars, and roasted nuts. Keano has a limited supply of nuts that are bought from local growers and it is barely able to meet the demand for their products. At the same time, increases in the cost of macadamia nuts and foreign competition make it difficult for Keano to maintain a reasonable profit. The demand for macadamia nut products fluctuates with seasonal tourist levels and so production is budgeted on a weekly basis.

\section{Relevant Input Data and Cost Accounting Computations}

Revenues, costs and other input data are italicized in Exhibit 2. By having an input section, changes can be made such that scenario analysis and even Monte Carlo simulation could be performed. Cost accounting computations drawn from the input data are also presented.

The selling price (SP) for Keano's four macadamia nut products Whole, Cluster, Crunch, and Roasted as $\$ 6.00, \$ 5.00, \$ 3.20$, and $\$ 4.50$ per pound; and the minimum sales demand are 1,000 pounds, 400 pounds, 200 pounds, and 100 pounds, respectively. The Crunch product, which is made from small pieces of the macadamia nuts, is popular with locals and has a maximum demand of 500 pounds.

During this time of the year, the local growers are able to harvest no more than the equivalent of 1,100 pounds of hulled macadamia nuts. The composition of macadamia nuts within one pound of a finished product varies, Whole $60 \%$, Cluster $40 \%$, Crunch $20 \%$, and Roasted $100 \%$, with chocolate making up the balance. The hulled macadamia nuts cost $\$ 1.60$ per pound, and chocolate costs $\$ 0.80$ per pound. Therefore, the direct material cost (DMC) for the Whole product is $\$ 1.28$, computed as $\$ .96(.6 * \$ 1.60)$ for nuts plus $\$ .32(.4 * \$ .80)$ for chocolate, Cluster is $\$ 1.12$, Crunch is $\$ 0.96$ and Roasted is $\$ 1.60$. 
Exhibit 2: LP Input Data and Cost Computations

\begin{tabular}{|c|c|c|c|c|c|}
\hline & Whole & Cluster & Crunch & Roasted & Constraint/Rate \\
\hline Selling price $(\mathrm{SP}) / \mathrm{lb}$ & 6.00 & 5.00 & 3.20 & 4.50 & \\
\hline \multicolumn{6}{|l|}{ Sales requirement in lbs } \\
\hline & 1 & & & & $>=1000 \mathrm{lbs}$ \\
\hline & & 1 & & & $>=400 \mathrm{lbs}$ \\
\hline & & & 1 & & $>=200 \mathrm{lbs}$ \\
\hline & & & & 1 & $>=100 \mathrm{lbs}$ \\
\hline & & 1 & & & $<=500 \mathrm{lbs}$ \\
\hline \multicolumn{6}{|l|}{ Direct materials use/lb: } \\
\hline Nuts & .60 & .40 & .20 & 1.00 & $<=1100 \mathrm{lbs}$ \\
\hline Chocolate & .40 & .60 & .80 & .00 & \\
\hline \multicolumn{6}{|l|}{ Direct materials cost/lb } \\
\hline Direct materials-Nuts & 0.96 & 0.64 & 0.32 & 1.60 & $\$ 1.60$ per $\mathrm{lb}$ \\
\hline Direct materials-Choc. & 0.32 & 0.48 & 0.64 & 0.00 & $\$ 0.80$ per $\mathrm{lb}$ \\
\hline Direct mat. cost (DMC) & 1.28 & 1.12 & 0.96 & 1.60 & \\
\hline \multicolumn{6}{|l|}{ Machine use in $\mathrm{min} / \mathrm{lb}$ : } \\
\hline Roast machine & 1.50 & 1.50 & 1.50 & 1.50 & $<=3600 \mathrm{~min}$ \\
\hline Chocolate machine & 1.80 & 1.00 & 0.80 & 0.00 & $<=3600 \mathrm{~min}$ \\
\hline Package machine & 1.80 & 1.60 & 1.40 & 1.00 & $<=3600 \mathrm{~min}$ \\
\hline \multicolumn{6}{|l|}{ Direct labor cost } \\
\hline Direct labor-Roast & 0.30 & 0.30 & 0.30 & 0.30 & $\$ .20$ per $\min$ \\
\hline $\begin{array}{l}\text { Direct labor- } \\
\text { Chocolate }\end{array}$ & 0.36 & 0.20 & 0.16 & 0.00 & $\$ .20$ per min \\
\hline Direct labor-Package & 0.18 & 0.16 & 0.14 & 0.10 & $\$ .10$ per min \\
\hline Direct labor cost & 0.84 & 0.66 & 0.60 & 0.40 & \\
\hline Variable manuf overhead & 0.32 & 0.28 & 0.24 & 0.40 & 0.25 of DMC \\
\hline Variable S\&A & 0.60 & 0.50 & 0.32 & 0.45 & 0.10 of SP \\
\hline Total variable cost & 3.04 & 2.56 & 2.12 & 2.85 & \\
\hline Contribution margin & 2.96 & 2.44 & 1.08 & 1.65 & \\
\hline
\end{tabular}

The labor costs are for time spent running the three machines - Roast, Chocolate and Package. Each product requires time on the machines except for the Roasted product which does not use the Chocolate machine. The number of minutes per pound of finished product required on each machine is listed in Exhibit 2 (for example, the Whole product requires 1.5 minutes on the Roast machine). Each machine is available 60 hours or 3,600 minutes per week. Variable labor costs in running the machines are $\$ 12$ per hour or $\$ 0.20$ per minute for the Roast and Chocolate machines, and $\$ 6$ per hour or $\$ 0.10$ per minute for the Package machine. Therefore, the direct labor cost for the Whole product is $\$ 0.84$, Cluster is $\$ 0.66$, Crunch is $\$ 0.60$, and Roasted is $\$ 0.40$.

Variable manufacturing overhead costs (e.g., sugar, salt, oil and garlic) are driven by direct materials costs (DMC) for the macadamia nuts and chocolate; therefore, it is applied at a rate of $25 \%$ of DMC. The variable S\&A expenses (e.g., commissions and delivery costs) are estimated to be $10 \%$ of the selling price (SP).

The total variable costs for the products are Whole $\$ 3.04$, Cluster $\$ 2.56$, Crunch $\$ 2.12$, and Roasted $\$ 2.85$. For example, the Whole product has $\$ 3.04$ total variable cost per unit, which consists of $\$ 1.28$ direct materials, $\$ .84$ of direct labor, $\$ .32$ variable manufacturing overhead, and $\$ .60$ variable selling and administrative. The contribution margins per unit, or selling price less total variable cost, are Whole $\$ 2.96$, Cluster $\$ 2.44$, Crunch $\$ 1.08$, and Roasted \$1.65.

\section{Linear Programming with Spreadsheet Add-In}

Exhibit 3 has sections for the LP Base Model and LP Solution. Although they appear separately, the Base Model becomes the Solution when linear programming is performed. The Base Model is useful in setting up the 
problem, and it is built by referring to the data in Exhibit 2. The Base Model has "10" as the decision or number of units for each product. An essential step in completing the Base Model is to include the decision cell containing " 10 " as a multiplicative factor in the columns below it for each product. For example, the contribution margin for Whole has the cell formula references for $10 * 2.96$. A method to check that references to the decision cell containing " 10 " is correct within the Base Model is to change the decision input from " 10 " to " 100 ", which should increases the columnar values below by a factor of 10 .

The LP Solution is generated from the SOLVER add-in to EXCEL with the following steps. Select Tools from EXCEL's standard toolbar and then Solver from the dropdown screen. If Solver is not available, then it must be added from the original Office software.

From the Solver Parameters screen that appears, perform the following (note that " $\wedge$ " means intersection).

1. $\quad$ Set Target Cell for Total ^ Contribution Margin (cell displaying 81.30).

2. $\quad$ Equal To Max to maximize the target cell.

3. By Changing Cells for the Decision (cells displaying 10 for the four products).

4. $\quad$ Subject to the Constraints:

Add constraint that Decision cells are $>=$ " 0 ".

Add constraint that Decision cells are = "integer".

Add that cells for Total ^ Nut Supply must be $<=$ " $1100 "$.

Add that cells for Total ^ Sales Requirements for Whole, Cluster, Crunch and Roasted must be $>=$ "1000", " $400 ", " 200 "$ and " $100 "$, respectively.

Add that cells for Total ^ Sales Requirements for Cluster must be $<=$ " $500 "$ ".

Add that cells for Total ^ Machine Use for the three machines must be $<=$ "3600".

5. Select OK and then Solve.

The LP Solution displayed in Exhibit 3 indicates that 1,209 pounds of Whole, 500 pounds of Cluster, 373 pounds of Crunch, and 100 pounds of Roasted generate a maximized \$5,366 of contribution margin. A review of all the constraints finds that none are being violated, and that the package machine is being fully utilized (rounding for the integer decision).

\section{Integrated Cost Accounting System with Linear Programming}

The integration of linear programming into the cost accounting system is completed through the contribution income statement found in Exhibit 1. The LP decision of Exhibit 3 has been forwarded to the spreadsheet contribution income statement. Of course, the cost information from the LP Solution is consistent with the costs on the contribution income statement. In retrospect, cost data to an LP problem was generated from the accounting system, the solution to a profit maximization LP problem was determined, and the solution itself was linked back into the cost accounting system.

Once the spreadsheet containing the input data, LP solution, and contribution income statement has been completed, users can make changes to the inputs in performing scenario analysis or Monte Carlo simulation. For example, higher costs for labor, hulled nuts or chocolate could be examined. Even a change in the hulled nuts available could be examined. The purchase of new equipment that would increase available minutes or reduce production time needed for each pound of finished product could be analyzed. This exercise can also be used to lead into a practical discussion for the theory of constraints. For example, by increasing the number of packaging minutes available through the purchase of another machine, a bottleneck could be resolved, throughput increased, and contribution margin increased.

\section{CONCLUSION AND SUGGESTIONS FOR FURTHER INTEGRATION}

Accounting students can easily couple their knowledge of relevant costs, contribution margin and variable costing systems with linear programming skills to solve profit maximization or cost minimization problems. 
Current cost/managerial accounting textbooks should further integrate their discussion of managerial decisionmaking with operations management techniques readily available with spreadsheets. As suggestions, flexible budgeting, cost-volume profit analysis and cost estimation rely on concepts for linear regression; cost estimation with learning present benefit from curvilinear analysis and modeling; and capital budgeting, cash flow statements and income statements adopt Monte Carlo simulation to assess risk.

Exhibit 3: LP Base Model and Solution

\begin{tabular}{|c|c|c|c|c|c|c|c|}
\hline LP Base Model & Whole & Cluster & Crunch & Roasted & Total & & \\
\hline Decision & 10 & 10 & 10 & 10 & 40 & & \\
\hline Max contrib. margin & 29.60 & 24.40 & 10.80 & 16.50 & 81.30 & & \\
\hline Nut supply in lbs & 6.00 & 4.00 & 2.00 & 10.00 & 22.00 & $<=$ & 1100 \\
\hline \multicolumn{8}{|l|}{$\begin{array}{l}\text { Sales requirements in } \\
\text { units: }\end{array}$} \\
\hline Whole & 10 & & & & 10 & $>=$ & 1000 \\
\hline Cluster & & 10 & & & 10 & $>=$ & 400 \\
\hline Crunch & & & 10 & & 10 & $>=$ & 200 \\
\hline Roasted & & & & 10 & 10 & $>=$ & 100 \\
\hline Cluster & & 10 & & & 10 & $<=$ & 500 \\
\hline \multicolumn{8}{|l|}{ Machine use in mins: } \\
\hline Roast machine & 15 & 15 & 15 & 15 & 60 & $<=$ & 3600 \\
\hline Chocolate machine & 18 & 10 & 8 & 0 & 36 & $<=$ & 3600 \\
\hline Package machine & 18 & 16 & 14 & 10 & 58 & $<=$ & 3600 \\
\hline LP Solution & Whole & Cluster & Crunch & Roasted & Total & & \\
\hline Decision & 1209 & 500 & 373 & 100 & 2182 & & \\
\hline Max contrib. Margin & 3578 & 1220 & 403 & 165 & 5366 & & \\
\hline Nut supply in lbs & 725 & 200 & 75 & 100 & 1100 & $<=$ & 1100 \\
\hline \multicolumn{8}{|l|}{$\begin{array}{l}\text { Sales requirements in } \\
\text { units: }\end{array}$} \\
\hline Whole & 1209 & & & & 1209 & $>=$ & 1000 \\
\hline Cluster & & 500 & & & 500 & $>=$ & 400 \\
\hline Crunch & & & 373 & & 373 & $>=$ & 200 \\
\hline Roasted & & & & 100 & 100 & $>=$ & 100 \\
\hline Cluster & & 500 & & & 500 & $<=$ & 500 \\
\hline \multicolumn{8}{|l|}{ Machine use in mins: } \\
\hline Roast machine & 1813 & 750 & 560 & 150 & 3273 & $<=$ & 3600 \\
\hline Chocolate machine & 2176 & 500 & 298 & 0 & 2974 & $<=$ & 3600 \\
\hline Package machine & 2176 & 800 & 522 & 100 & 3598 & $<=$ & 3600 \\
\hline
\end{tabular}

\section{REFERENCES}

1. Albright, S. Christian and Wayne L. Winston, Spreadsheet Modeling and Applications, Thomson/Brooks Cole, Belmont, California, 2005.

2. Garrison, Ray. H., Eric W. Noreen and Peter C. Brewer, Managerial Accounting, McGraw-Hill//rwin, New York, 2006.

3. Hilton, Ronald. W., Michael W. Maher and Frank H. Selto, Cost Management: Strategies for Business Decisions, McGraw-Hill/Irwin, New York, 2003.

4. Horngren, Charles T., George Foster and Srikant M. Datar, Cost Accounting: A Managerial Emphasis, Prentice-Hall, Upper Saddle River, New Jersey, 2006. 